\title{
Ralstonia solanacearum: the bacterial wilt causal agent
}

\begin{abstract}
Ralstonia solanacearum (race 3 biovar 2) is a bacterial wilt causal agent of many plant species. Infects (potatoes Solanum tuberosum, eggplant Solanum melongena, peppers Capsicum annuum, tomatoes Lycopersicon esculentum, geraniums, Geranium carolinianum, ginger Zingiber officinale and a few weed species including bittersweet Celastrus orbiculatus, nightshade Solanum karsense and stinging nettle Urtica dioica. Ralstonia solanacearum can be infectious in the soil for years in the presence of a host. Race 3 biovar 2 is most commonly transmitted by contaminated soil, equipment, water and insect, or by transplantation of infected seeds or seedlings. Management requires use of resistance cultivars, clean and certified seed, good cultural practices, some chemicals fumigation, antagonistic microbes as a biological control like (Mycorrhizal fungi, Streptomyces sp. and Tricoderma sp.) transgenic resistant plant, cropping systems, soil amendments, integrated control, genetically engineered antagonistic and virulent mutants of R. solanacearum.
\end{abstract}

Keyword: Ralstonia solanacearum; Bacterial wilt; Biological control; Resistance cultivars 